\title{
Distribution Channel Patterns and The Actors Welfare of Marine Fishery Supply Chain in Arjasa, Kangayan and Sapeken in Kangean Islands
}

\begin{tabular}{|c|}
\hline Kurniyati Indahsari'), Akhmad Farid ${ }^{2)}$ \\
${ }^{1)}$ Faculty of Economics and Business, Universitas Trunojoyo Madura \\
${ }^{22}$ Faculty of Agriculture, Universitas Trunojoyo Madura \\
Corresponding Author: kurniyati.indahsari@trunojoyo.ac.id
\end{tabular}

Recieved: November 2019 | Revised: March 2020 | Accepted: March 2020

\begin{abstract}
The actors' welfare of marine fishery supply chain in the three sub-districts in Kangean Islands, namely Sapeken, Arjasa and Kangayan, are different even though they access to the same marine fisheries resources. The marine fisheries in Sapeken are more prosperous than those in Arjasa and Kangayan. This study aimed at identifying the distribution channel patterns of marine fishery products supply chain in Kangean Islands which providing an explanation of the actors' welfare differences. In-depth interviews with various actors were conducted to formulate the distribution channel patterns of marine fishery products. Quantitative survey data of 102 respondents from marine fisheries were processed descriptively to determine the actors' welfare. Research showed that the distribution channel patterns in Arjasa and Kangayan vary but are limited in the local market and the islands communities as the final consumers. It causes the low products prices. Meanwhile, the distribution pattern in the Sapeken is able to penetrate markets outside the Kangean Islands with high product prices. Therefore, it is not surprising if the actors' welfare in Arjasa and Kangayan sub districts are lower than the actors' welfare in Sapeken.
\end{abstract}

Keywords: marine fishery distribution channel; marine fishery market; marine fisheries welfare, JEL classification: D30, D40, D60

How to Cite: Indahsari, K., Farid, A. (2020). Distribution Channel Patterns and The Actors Welfare of Marine Fishery Supply Chain in Arjasa, Kangayan and Sapeken in Kangean Islands. Jurnal Ekonomi Pembangunan: Kajian Masalah Ekonomi dan Pembangunan, 21(1). 14-22. doi:https://doi. org/10.23917/jep.v21i1.9379

DOI: https://doi.org/10.23917/jep.v21i1.9379

\section{Introduction}

The islands development has more challenges and problems than the mainland development. Sudrajat (2013) and Nurlaili et al. (2014) showed that the main problems of islands development are regional isolation and limited infrastructures as well as the community structures which lead to social polarization. Ginting (2013) also mentioned that geographical conditions which complicate regional development, the low general allocation funds received from the central government, and limited education and health services are the islands main development problems. Meanwhile, Syahza \& Suarman (2013) stated that the islands poverty causes are the development biases and distortions which more favor on the urban economy development, the weak capital structure and limited access to capital sources as 
Jurnal Ekonomi Pembangunan: Kajian Masalah Ekonomi dan Pembangunan, 21 (1), 2020, 14-22

well as the limited soil fertility, procurement and distribution of production facilities and the ability of technological mastery.

The development of main economic sector in the islands, i.e. the capture fisheries sector, also faces various obstacles. Firstly, the communities who are generally small fishermen or fishing laborers have limited ownership of fishing equipment. Secondly, they generally have limited knowledge and practices on modern fishing technology/limited human resource capacity, so that the capture fish production is also limited. Thirdly, the climate/weather constraints that cause the fluctuate captured fish as well as the fluctuate marine fishery products prices. The Fluctuations of fish catch volume and prices cause the fishermen revenue fluctuations. Fourthly, the threat of overfishing which causes the environmental unsustainability if fishermen capture large-scale marine products or use fishing gear that endangers the marine environment (Hidayat, 2010; Syahza \& Suarman, 2013; Nurlaili et al., 2014). Tangke (2011) added the challenge of developing a fisheries business in Indonesia is the weakness of the fisheries data and information system which results in misplaced planning and leads to business failure. These obstacles commonly lead the low level of fishermen' welfare.

Sumenep Regency is an area that has the second largest number of islands in Indonesia, so that it has potential coastal, fishery and marine resource. Kangean Islands are part of Sumenep Regency which have a group of islands and great potential marine fisheries, product-based industries and marine tourism. The Kangean Islands only consists of 3 of 27 sub-districts in Sumenep Regency, but its area covers $24.37 \%$ of Sumenep Regency's area (Sadik, 2012; Siswanto \& Nugroho, 2016). Kangean Islands also produce a variety of high-quality and high-value reef fish, seaweed and coconut. In addition, the community in this sub-district has also been able to produce processed seafood (such as squid), cultivate seaweed and pearl oysters, and trade in high quality fish (Sadik, 2012).
As an archipelago, the regional development of Kangean Islands faces the same challenges as the common islands' development. There are limited connectivity and accessibility to Kangean Islands from the center of Sumenep Regency, as well as within subdistricts, both by road and by sea. The distance of the Kangean Islands from Kalianget Harbor (mainland of Sumenep Regency) is about 112 miles reached by ships. There are also transportation facilities, i.e motorized sailboats which connect islands in the Kangean archipelago. However, the operational time of these transportation facilities is limited since it depends on the good weather for safety sailing. When people and goods / services mobility is disrupted, the economic costs are high and reduce the regional economic activities. Public infrastructures, such as the quantity and quality of water infrastructure, electricity, telecommunications, and transportation are limited. The limited human resources quality is still a common obstacle to the islands' development (Sadik, 2012; and Siswanto \& Nugroho, 2016).

Various obstacles in the marine fisheries sector development are found in the Kangean Islands. In the seaweed sector, it is found obstacles, i.e.: (1) high operational costs and limited capital, (2) low bargaining power of farmers, (3) lack of knowledge of farmers, (4) weather conditions and the presence of disease / predators, (5) lack of government attention, and (6) lack of farmer and economic institutions (Nurwidodo et al., 2017). Meanwhile, capture marine fisheries are threatened to be unsustainable if fishing practices still utilize equipment which is not environmentally friendly, such as potassium and trawl uses, as well as environmental degradation due to the human activity pressure (Indahsari \& Farid, 2016). Danial (2014) also showed that the potassium used in fishing and the presence of illegal ships and fishermen from outside the Kangean also negatively affected the island fishermen welfare.

In addition, the welfare level of the fishing communities in the three sub-districts in the Kangean Islands, namely Sapeken, Arjasa and

Jurnal Ekonomi Pembangunan, ISSN 1411-6081, E-ISSN 2460-9331 
Kangayan, is different even though they have the same access to the same fisheries and marine resources. Marine fisheries actors in Sapeken sub district have a relatively higher welfare level than the actors of two other districts (Indahsari \& Farid, 2016).

Several studies, such as carried out by Jumiati (2012) and Fatmawati (2016) showed the relationship between the distribution of marine fishery product channels and the fishermen income. Studies generally concluded that the shorter distribution channel is the more efficient, while the highest margins is in the actor who can add value to the product during the supply chain. In addition, fishermen or producers are still the party who gets the lowest margin or share, so that affects their low income. Therefore, this study aimed at identifying the distribution channel pattern of marine fisheries products supply chain in three sub districts in the Kangean Islands which providing an explanation of the different level of actor's welfare.

\section{Research Method}

Some studies related to distribution or marketing channels for fishery products are generally carried out on specific marine fisheries products and accompanied by calculation of margins and marketing efficiency of these products, as conducted by Jumiati (2012), Fatmawati (2016), Sarwanto et al. (2014) and Ramizan et al. (2014). Generally, these studies used in-depth interviews with actors in the distribution channel of marine fishery products that are selected by purposive or snowball sampling to find out the distribution channel. The efficiency level is found out by calculating the farmer's/fishermen's share, i.e, a percentage of the price received by fishermen compared to the price received by consumers. The marketing margins are calculated in total or per distribution channel actor by subtracting the income received by consumers from the income received by consumers.

This research used quantitative and qualitative approaches. A survey had collected data of 102 respondents who selected purposively from unidentified population number in three sub districts in Kangean Islands. In each subdistrict the respondents were chosen accidently from marine fisheries actors, namely small, medium and large scale fishermen as well local and regional fish traders/collectors. Local traders or collectors mean they operate within the subdistrict (small scale traders/collectors), while the regional traders or collectors' activities covers outside the sub-district (medium traders) or even outside the Kangean Islands (large traders). The data collected is the respondents' income and expenditure to calculate the actors exchange rate, an indicator of welfare level. The mean comparison test of fisheries actors income is also applied to test the mean of actors income differences among three sub-districts in Kangean Islands.

In addition, the survey also collected qualitative information about the relationships or rules that apply between marine fisheries actors, both in the same sub-district, between sub-districts or with parties outside the islands. Informants who're in-depth-interviewed were several people (among respondents) who were judged to understand the focus of this study.

The results of in-depth interviews with various actors were used to formulate the distribution channel pattern of marine fisheries products in the three sub districts. Meanwhile, quantitative survey data on 102 respondents were processed descriptively to calculating the welfare level of each actor in the distribution channel of marine fisheries products supply chain.

\section{Results and Discussion}

Research showed that the institutions of marine fishery production and distribution in Sapeken sub district are richer than those in Arjasa and Kangayan sub districts. Identified institutions in Arjasa and Kangayan are: (i) the relationship between fishing laborers and fishermen in the capture fisheries process. The existing institution or system is the revenue sharing between the two parties. The research showed that the fishermen or the fishing gear 
and capital owner will get a larger portion of the revenue share than the fishing laborers; (ii) Fishermen in Arjasa and Kangayan use traditional fishing gears. The average length of catching fish is only a half day, so that the number of catch fish also limited; (iii) the relationship among fishermen, local or regional traders, fish processors and household consumers. The existing institution among them is selling and buying relationships; (iv) the distribution channels vary but are limited in local areas, i.e, within sub district or between Arjasa and Kangayan sub districts; (v) For high qualified fresh fish or live fish, fishermen sell them to the only one collector in Arjasa and Kangayan. The collector is from Sapeken and act as price maker. High qualified fresh or live fish means fish which have high demand from outside the Kangean Islands.

Meanwhile, the production and distribution institutions in Sapeken has more variation. The identified marine fisheries institutions in Sapeken are: (i) the relationship between fishing laborers and fishermen in the capture fisheries process with revenue sharing system; (ii) fishermen in Sapeken have been using modern fishing gears. The average length of catching fish is 3-4 days per period, so that the more and various fish catches; (iii) generally, traders or collectors will provide various production infrastructure or cash money to the fishermen. As long as the fishermen are still committed to sell their products to the traders / collectors, all production infrastructure and cash money will be held by the fishermen. If at any time the fishermen do not want to sell their products to the collectors, all production facilities, including cash money, must be returned to the collectors. It was recognized that there is competition between collectors, so that, fishermen can freely decide to select the best collectors as their partners; (iv) there're more actors in Marine fisheries supply chain in Sapeken. Besides the actors mentioned in Arjasa and Kangayan above, there're also net or small capture fishermen, small and large collectors, as well as marine fish enlargement cultivator; the relationships among them are buying and selling marine products, especially fresh and live fish which high demand as well as prices; (v) Relationship between small and large collectors are seen in Sapeken District. Small collectors are intermediaries between fishermen and large collectors with sale and purchase occur between them. At present the number of small collectors has begun to decrease because most fishermen prefer to sell their products directly to large collectors in Sapeken Island; (vi) large collectors act as large scale traders who sell fresh or live fish outside Kangean Islands; (vii) The final consumers not only the households in Kangean islands, but mostly corporate consumers in Bali and Banyuwangi. Like the relationship between fishermen and collectors, corporate consumers outside Kangean Islands can provide capital for the collectors in Sapeken, to ensure that the collectors will sell their products to them. Sapken collectors acknowledge that there is competition between corporate consumers outside Kangean Islands; (viii) the relationship between collectors and non-fishery traders in Sapeken. Nonfishery traders need goods purchased by collectors when selling their products in Bali or Banyuwangi. On the other hand, the collectors need cash for their transaction with fishermen which can be prepared by non-fishery traders. Figure 1 shows that the distribution channel patterns in Arjasa and Kangayan vary but are limited in the local market and the islands communities as the final consumers. It causes the low products prices. Meanwhile, the distribution pattern in the Sapeken is able to penetrate markets outside the Kangean Islands with high product prices.

Institutions of marine fisheries production and distribution in Sapeken are more various and longer, but the actors' income in these areas is better than those in Arjasa and Kangayan. This can be understood because Sapeken marine fisheries products already have a wider market with relatively high prices. This condition is also in accordance with the study conducted by Wamukota et al. (2014) that when the fish market has expanded (there is market integration), more actors will be involved in the supply chain with high income, even though the inequality income among actors is also high. 


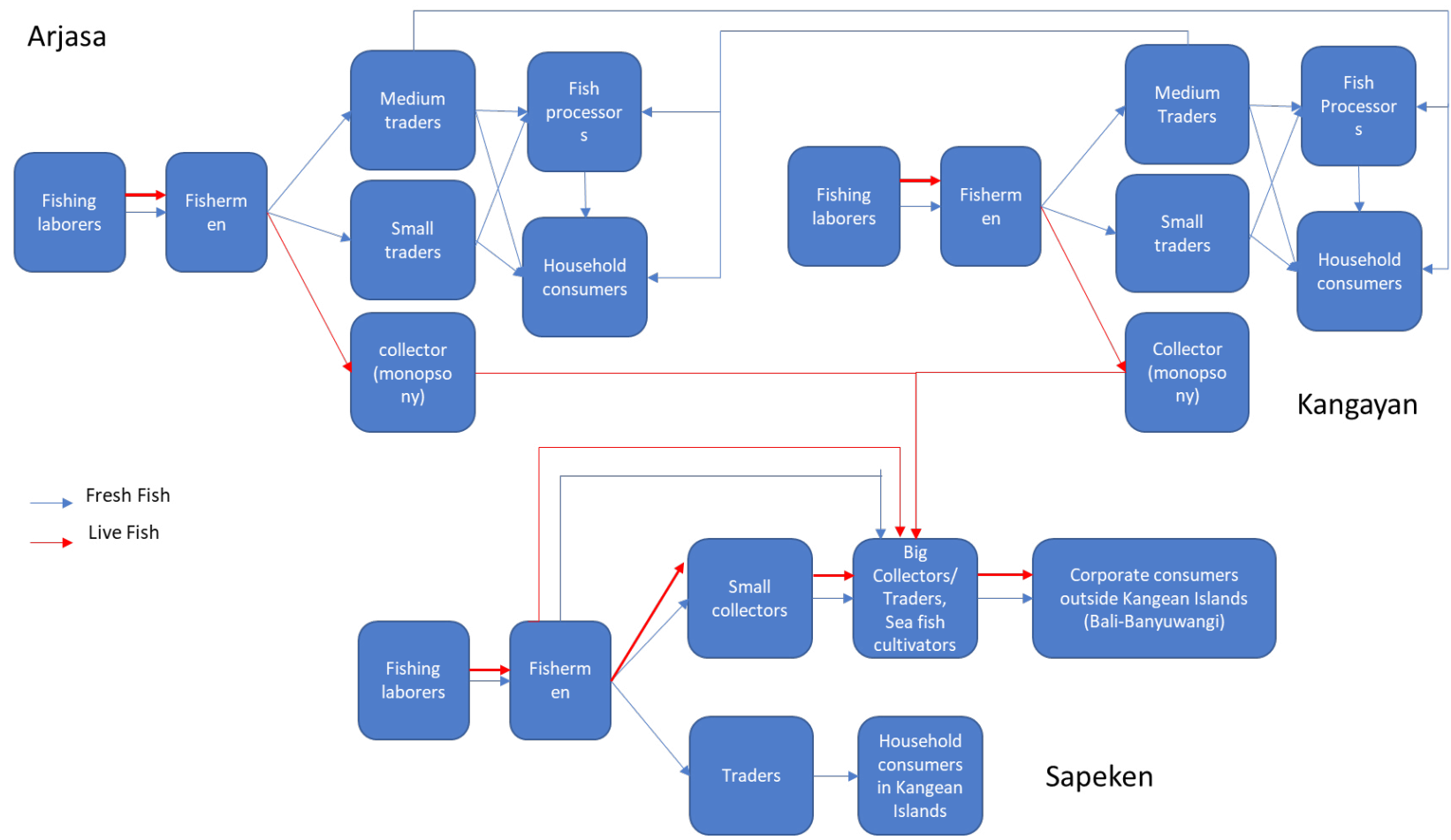

Figure 1. Distribution Pattern of Kangean Islands Sea Fisheries Product Distribution Channel

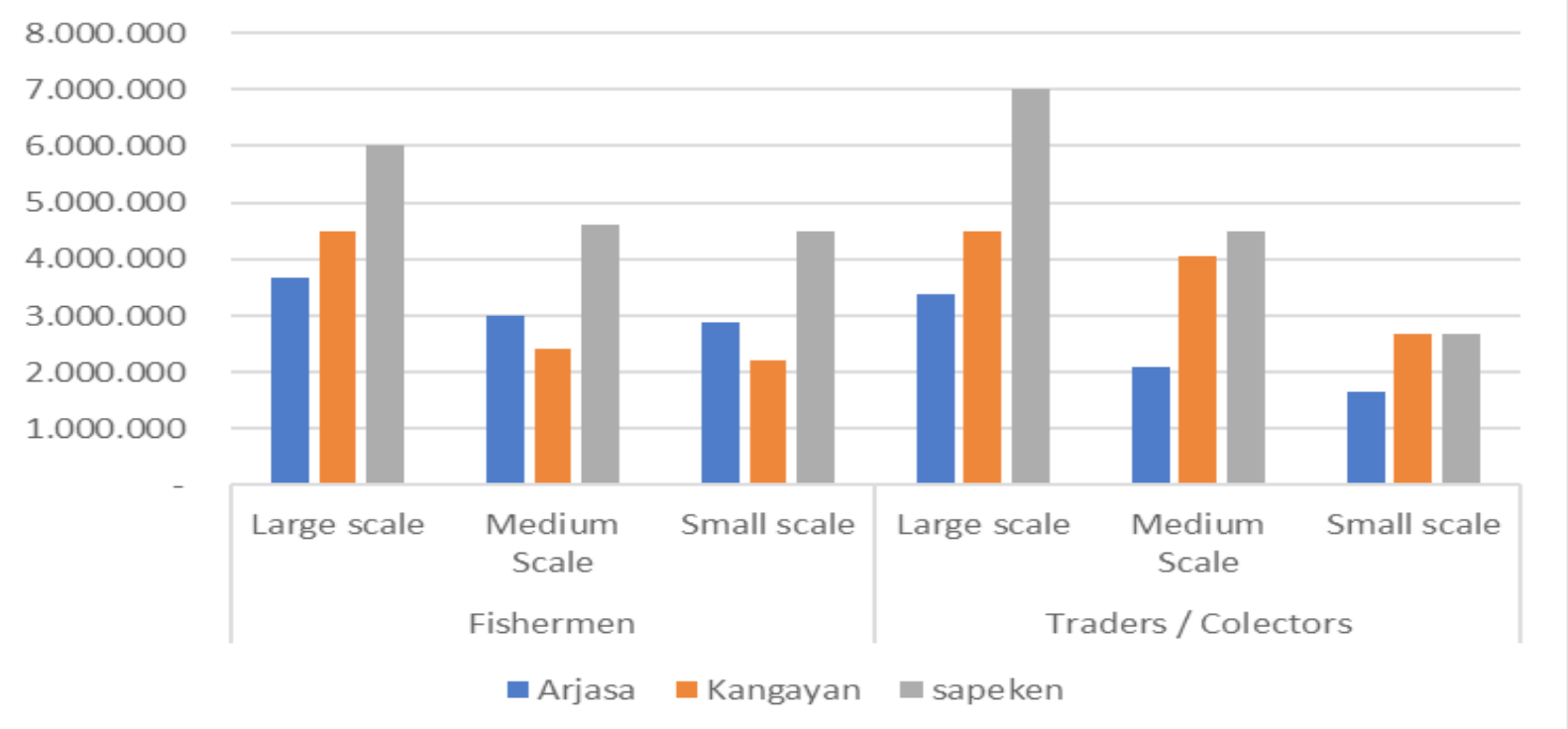

Figure 2. The Average of Marine Fisheries Distribution Channel Actors' Income in the Kangean Islands (Rupiah per Month)

Source: Processed survey data, 2019

Distribution channel patterns create traders in selling their products. Consumers different types of fish markets. The relatively are local community with limited numbers. So limited fresh fish market in Arjasa and Kangayan that, the fresh fish market is often excess supply implies the intense competition of fishermen or which implies the low fish prices. The market 
for high quality fish in Arjasa dan Kangayan is monopsony since there's only one fish collector in these areas, so that the fishermen are price taker. In addition, fresh fish which are perishable products also affects the behavior of fishermen who tend to sell to those who guarantee the product is sold. This condition is certainly in accordance with the demand-supply theory in a variety of microeconomic literature. Studies conducted by Hamid (2012), Johanson (2013), and Ismail et al. (2008) showed how limited access to markets make marine fisheries tend to sell their products to the nearest first collectors who guarantee their catches sell quickly, with fishermen as prices takers. Johanson (2013) also showed that fishermen can actually get better prices if they sell directly to collectors 2 (larger collectors), but due to limited coverage, they prefer to receive prices at first collector.

Market limitation is a major problem in the marine fisheries development in Arjasa dan Kangayan sub-districts, so that, a strategy to export products outside the region is a must. The distribution channel pattern as happened in Sapeken sub district should also be carried out by these sub districts. The same suggestion was conveyed in a study conducted by Oktary et al. (2016) for the high total production of purse seine catching but could not be absorbed by the local market. Mahatama, E., \& Farid (2013) also showed how the channels of marine fishery products sold to exporters are more profitable marketing channels.

Product marketing is the most important thing in fishery business because it influences the income level of fishermen (Maisyaroh, N., \& Boesono, 2014; Ismail et al., 2008). Therefore, the limitations of distribution channels in Arjasa and Kangayan sub-Districts imply for the relatively low income of marine fisheries actors. It can be seen that all actors of marine fishery products distribution channel in Sapeken sub district have relatively higher income than those in Arjasa and Kangayang (Figure 2). Table 1 also shows that the fisheries actors income in Sapeken sub districts are higher significantly than the fisheries actors income in Sapeken in Arjasa and Kangayan.

Table 1. Comparison Test of Fisheries Actors Income among Three Sub-District in Kangean Islands

\begin{tabular}{|c|c|c|c|c|c|c|c|c|c|}
\hline Actors & $\begin{array}{c}\text { Sub- } \\
\text { District }\end{array}$ & $\begin{array}{l}\text { Income } \\
\text { Mean }\end{array}$ & F-Test & Sig. & Actors & $\begin{array}{c}\text { Sub- } \\
\text { District }\end{array}$ & $\begin{array}{l}\text { Income } \\
\text { Mean }\end{array}$ & F-Test & Sig. \\
\hline \multirow{3}{*}{$\begin{array}{l}\text { Fisheries } \\
\text { household } \\
\text { (All actors) }\end{array}$} & Arjasa & 2.770 .833 & \multirow[t]{3}{*}{15,209} & \multirow[t]{3}{*}{0,000} & \multirow{3}{*}{$\begin{array}{l}\text { Small } \\
\text { scale } \\
\text { fishermen }\end{array}$} & Arjasa & 2.875 .000 & \multirow[t]{3}{*}{1,965} & \multirow[t]{3}{*}{0,186} \\
\hline & Kangayan & 3.064 .167 & & & & Kangayan & 2.200 .000 & & \\
\hline & Sapeken & 4.833 .333 & & & & Sapeken & 4.500 .000 & & \\
\hline \multirow[t]{3}{*}{ Fishermen } & Arjasa & 3.136 .364 & \multirow[t]{3}{*}{8,697} & \multirow[t]{3}{*}{0,001} & \multirow{3}{*}{$\begin{array}{l}\text { Large } \\
\text { scale } \\
\text { Traders }\end{array}$} & Arjasa & 3.375 .000 & \multirow[t]{3}{*}{16,200} & \multirow[t]{3}{*}{0,028} \\
\hline & Kangayan & 3.227 .273 & & & & Kangayan & 4.500 .000 & & \\
\hline & Sapeken & 5.235 .294 & & & & Sapeken & 7.000 .000 & & \\
\hline \multirow{3}{*}{$\begin{array}{l}\text { Traders / } \\
\text { Collectors }\end{array}$} & Arjasa & 2.416 .667 & \multirow[t]{3}{*}{3,486} & \multirow[t]{3}{*}{0,133} & \multirow{3}{*}{$\begin{array}{l}\text { Medium } \\
\text { scale } \\
\text { Traders }\end{array}$} & Arjasa & 2.100 .000 & \multirow[t]{3}{*}{32,899} & \multirow[t]{3}{*}{0,003} \\
\hline & Kangayan & 2.926 .154 & & & & Kangayan & 4.040 .000 & & \\
\hline & Sapeken & 3.857 .143 & & & & Sapeken & 4.500 .000 & & \\
\hline \multirow{3}{*}{$\begin{array}{l}\text { Large scale } \\
\text { fishermen }\end{array}$} & Arjasa & 3.666 .667 & \multirow[t]{3}{*}{1,729} & \multirow[t]{3}{*}{0,238} & \multirow{6}{*}{$\begin{array}{l}\text { Small } \\
\text { scale } \\
\text { Traders }\end{array}$} & Arjasa & 1.666 .667 & \multirow[t]{6}{*}{2,967} & \multirow[t]{6}{*}{0,084} \\
\hline & Kangayan & 4.500 .000 & & & & Kangayan & 2.681 .818 & & \\
\hline & Sapeken & 6.000 .000 & & & & Sapeken & 2.666 .667 & & \\
\hline \multirow{3}{*}{$\begin{array}{l}\text { Medium } \\
\text { scale } \\
\text { fishermen }\end{array}$} & Arjasa & 3.000 .000 & \multirow[t]{3}{*}{1,929} & \multirow[t]{3}{*}{0,201} & & & & & \\
\hline & Kangayan & 2.400 .000 & & & & & & & \\
\hline & Sapeken & 4.600 .000 & & & & & & & \\
\hline
\end{tabular}




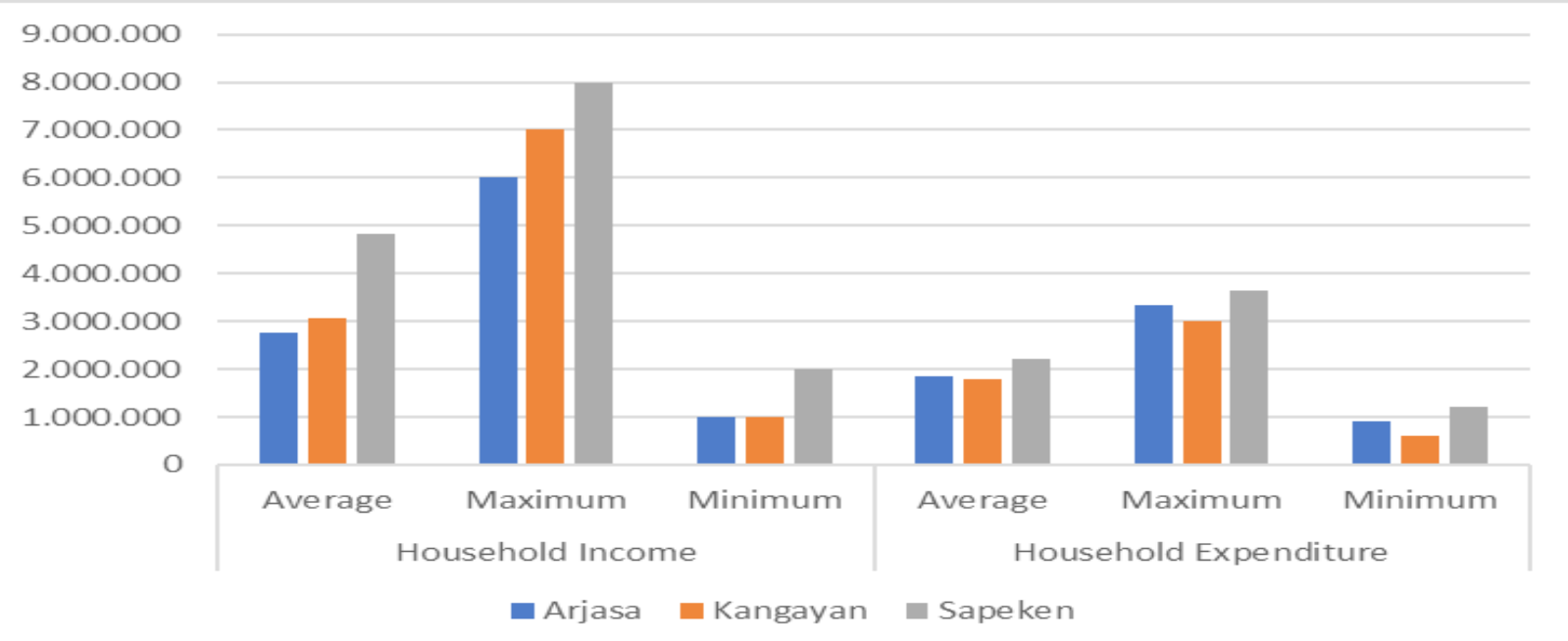

Figure 3. Descriptive Statistics of Fisheries Household Income and Expenditure in Three Sub Districts in Kangean Islands (Rupiah per Month)

Source: Processed survey data, 2019

The low income of marine fishery households in Arjasa and Kangayan Districts may also be caused by the low work participation of their household members. Marine fisheries households generally characterized by the work participation of other household member, especially fishermen wives, who contributes to family/household income as well as need fulfilment (Firdaus, M., \& Rahadian, 2015; Subaidi et al., 2015; Hutapea et al. 2012; and Nugraheni et al., 2012). However, the work participation of marine fisheries households members in the Kangean Islands differs from the common cases.

Survey showed that the number of household member of $95 \%$ fishery households in Kangean Islands is one person, either as a fisherman or trader. It means that it's only about $5 \%$ of respondents in the survey have more than one household member who're working. In addition, marine fishery actors who have side jobs are also limited. Survey showed that it's about $12.5 \%$ of respondents who have side jobs. Thus, it is not surprising that welfare level of marine fisheries households in the Kangean Islands, especially in Arjasa and Kangayan sub-districts is relatively low (Figure 3). The calculation of marine fishery household exchange rate - as measurement of household welfare - shows that on average, the exchange rates of marine fisheries in Arjasa and Kangayan sub districts are 1.49 and 1.71. Meanwhile the exchange rate of marine fisheries in Sapeken sub district is higher, at 2.19, and reflects that they are more prosperous than marine fisheries in Arjasa and Kangayan.

\section{Conslusions}

The institutions of marine fishery production and distribution in Sapeken are much better than those in Arjasa and Kangayan. The marine fisheries in Sapeken use more modern fishing gears than the marine fisheries in Arjasa and Kangayan. The distribution pattern of marine fishery products in Arjasa and Kangayan subdistricts vary but locally limited. Products are generally sold in the local market and the final consumers are local community, so that the selling price is low. Meanwhile, the distribution pattern of marine fishery products in Sapeken sub district, especially live and fresh fish commodities, are able to penetrate markets outside the region (Banyuwangi and Bali) with high selling prices. Therefore, it is not surprising that the marine fisheries income in Arjasa and Kangayan sub districts is lower than the marine fisheries income in Sapeken sub district. In addition, the low income of marine fishery households in Arjasa 
Jurnal Ekonomi Pembangunan: Kajian Masalah Ekonomi dan Pembangunan, 21 (1), 2020, 14-22

and Kangayan Districts may be caused by the low work participation of their household members.

To improve the marine fisheries welfare, it is necessary to expand the distribution channels of marine fisheries. Market limitation is a major problem in the marine fisheries development in Arjasa dan Kangayan sub-districts, so that, a strategy to export products outside the region is a must. It is very important to build and implement an institutional model of production and distribution channels for marine fisheries products in the Kangean Islands. The model utilizes the institutional concept of collective action among fishermen, collectors or traders. With collective action it is hoped that competition between them can be reduced and can jointly seek to improve mutual prosperity, for example in obtaining fisheries production facilities, shipping, and marketing as well as guaranteeing the stability of raw material and product prices.

\section{Acknowledment}

This paper is an output of Research titled Penguatan Kelembagan Produksi dan Saluran Distribusi Produk Perikanan Laut Terpadu di Kepulauan Kangean (The Institutional Strengthening of The Integrated Marine Fishery Production and Distribution in Kangean Islands). The research is funded by Lembaga Penelitian dan Pengabdian kepada Masyarakat (Research and Community Services Institute) University of Trunojoyo Madura using Non-Tax State Revenues Fund (PNBP) 2019.

\section{References}

Danial, S. (2014). Interaksi Nelayan Mandar dan Madura Kangean.

Fatmawati, F. (2016). Rantai Distribusi Ikan Tangkap di Desa Pohuwato, Timur Kecamatan Marisa. Jurnal Agropolitan, 3(3), 33-44.

Firdaus, M., \& Rahadian, R. (2015). Peran istri nelayan dalam meningkatkan pendapatan rumah tangga (Studi Kasus Di Desa Penjajab, Kecamatan Pemangkat,
Kabupaten Sambas). Jurnal Sosial Ekonomi Kelautan Dan Perikanan, 10(2), 241-249.

Ginting, A. M. (2013). Kendala Pembangunan Provinsi Daerah Kepualauan: Studi Kasus Provinsi Kepulauan Riau. Politica, 4(1), 49-75. Retrieved from http://bakohumas. kominfo.go.id/news.php?id=1000,

Hamid, S. K. (2012). Analisis efisiensi pemasaran rumput laut (Eucheuma cottonii) di Kota Tual Provinsi Maluku. Agrikan. Jurnal Ilmiah Agribisnis Dan Perikanan, 5(1), 57-70.

Hidayat, G. (2010). Budidaya Perikanan Laut dan Pantai sebagai alternatif pemenuhan kebutuhan produksi ikan nasional.

Hutapea, R., Kohar, A., \& Rosyid, A. (2012). Peranan Wanita Nelayan (Istri Nelayan) Jaring Insang dalam Meningkatkan Pendapatan Keluarga di Desa Bejalen, Perairan Rawa Pening, Kecamatan Ambarawa, Kabupaten Semarang. Journal of Fisheries Resources Utilization Management and Technology, 1(1), 1-10.

Indahsari, K., \& Farid, A. (2016). Prospek Pembudidayaan Perikanan Laut di Kecamatan Sapeken Kabupaten Sumenep. Unpublished Work Paper.

Ismail, G, Supardi, S, dan Wahyuningsih, S. (2008). Analysis Efficiensy Marketing System of Fresh Layang Fish (Decapterus russeli) on Pelabuhan Fish Auction Places in Tegal. Mediagro, 4(2), 39-50.

Johanson, D. (2013). Analisis Efisiensi Pola Distribusi Hasil Penangkapan Ikan Nelayan Kecamatan Kahayan Kuala Kabupaten Pulang Pisau. Jurnal Sains Manajemen , 1(1), 96-109.

Jumiati. (2012). Analisis Pemasaran dan Tingkat Pendapatan Nelayan pada Agribisnis Pengasapan Ikan Cakalang (Katsuwonus Pelamis)(Studi Kasus di Kecamatan Bontotiro Kabupaten Bulukumba). Jurnal 
Jurnal Ekonomi Pembangunan: Kajian Masalah Ekonomi dan Pembangunan, 21 (1), 2020, 14-22

Lmu Perikanan, 1(1), 45-53.

Mahatama, E., \& Farid, M. (2013). Daya saing dan saluran pemasaran rumput laut: kasus Kabupaten Jeneponto, Sulawesi Selatan. Buletin Ilmiah Litbang Perdagangan, 7(1), $55-72$.

Maisyaroh, N., \& Boesono, H. (2014). Analisis Pemasaran Hasil Tangkapan Lobster (Panulirus SP) Di Tempat Pelelangan Ikan (Tpi) Se-kabupaten Gunungkidul. Journal of Fisheries Resources Utilization Management and Technology, 3(3), 131140.

Nugraheni, W., Marhaeni, T., \& Sucihatiningsih, D. W. P. (2012). Peran dan potensi wanita dalam pemenuhan kebutuhan ekonomi keluarga nelayan. Journal of Educational Social Studies, 1(2).

Nurlaili, Witomo, C. M., Zamroni, A. (2014). Potensi dan Permasalahan Sosial Ekonomi Masyarakat Perikanan Kabupaten Lombok Timur dalam Mendukung Industrialisasi. Buletin Riset Sosek Kelautan dan Perikanan (Vol. 9).

Nurwidodo, Rahardjanto, A., Husamah, As'odo, \& Mufrihah, A. (2017). Potensi, Kendala, dan Strategi Pengembangan Budidaya Rumput Laut Berbasis Kolaborasi di Daerah Kepulauan Sapeken Kabupaten Sumenep. "Biologi, Pembelajaran, Dan Lingkungan Hidup Perspektif Interdisipliner," 350-360. Retrieved from http://research-report.umm. ac.id/index.php/

Oktary, R., Baso, A., \& Arief, A. A. (2016). Produksi Dan Pemasaran Perikanan Tangkap Unit Penangkapan Purse Seine Di Kecamatan Galesong Utara, KabupatenTakalar.

Ramizan, D., Yulinda, E., \& Bathara, L. (2014). Analisis Kelembagaan Pemasaran dan Margin Tataniaga Hasil Perikanan Tangkap di Desa Buluh Cina Kecamatan Siak Hulu Kabupaten Kampar Provinsi Riau. Jurnal Online Mahasiswa Fakultas
Perikanan Dan Ilmu Kelautan Universitas Riau, 1(1), 1-5.

Sadik, J. (2012). Karakteristik Wilayah Kepulauan Kabupaten Sumenep. CV. Diaspora.

Sarwanto, C., Wiyono, E. S., Nurani, T. W., \& Haluan, J. (2014). Kajian Sistem Pemasaran Ikan Hasil Tangkapan Nelayan di Kabupaten Gunung Kidul, Provinsi DIY. Jurnal Sosial Ekonomi Kelautan Dan Perikanan, 9(2), 207-217.

Siswanto, A. ., \& Nugroho, W. . (2016). Permasalahan dan Potensi Pesisir di Kabupaten Sampang. Jurnal Kelautan, 9(1).

Subaidi, Sidiq, M., \& Rahmawati, A. (2015). Peran Istri Nelayan dalam Pemenuhan Kebutuhan Keluarga. Ilmu Kesejahteraan Social, 1(1), 1-16.

Sudrajat, J. (2013). Potensi dan Problematika Pembangunan WIlayah Pesisir di Kalimantan Barat. Jurnal Social Economic of Agriculture (Vol. 2).

Syahza, A., \& Suarman, D. (2013). Strategi Pengembangan Daerah Tertinggal dalam Upaya Percepatan Pembangunan Ekonomi Pedesaan. Jurnal Ekonomi Pembangunan (Vol. 14).

Tangke, U. (2011). Pemanfaatan Sistem Informasi Perikanan dalam Pengelolaan Sumberdaya. Jurnal Ilmiah Agribisnis Dan Perikanan, 4(2), 52-59.

Wamukota, A., Brewer, T. D., \& Crona, B. (2014). Market Integration and Its Relation to Income Distribution and Inequality among Fishers and Traders: The Case of Two Small-Scale Kenyan Reef Fisheries. Marine Policy, 48, 93-101. 